\title{
Peningkatan Keterampilan Menulis Karangan Narasi dengan Menggunakan Model Cooperative Learning Type Concep Sentences
}

\section{Lely Medyawati}

Universitas Sebelas Maret

lelymedyaw@gmail.com

\section{Article History}

received 30/4/2021

\begin{abstract}
The research was based on the results of narrative essay writing skills written not achieved the minimum completion criteria (KKM). The research aims to improve the writing skills of narrative composition by applying cooperative learning model type concept sentences in grade IV students of SDN Soropadan in the 2020/2021 school year. This research is a class action research with planning, implementation, observation, and reflection measures carried out in three cycles. The results showed an increase in classical completion from $39 \%$ with an average value of 75.42 to $67 \%$ and an average value of 80.97 in cycle I, 89\% and an average value of 84.58 in cycle II and $94 \%$ with an average of 87.92 in cycle III. The conclusion of the study is the application of cooperative learning model type concept sentences can improve the writing skills of narrative composition in grade IV students of SDN Soropadan Surakarta in the 2020/2021 school year.
\end{abstract}

Keywords: Writing Skills, Narrative Writing, Concepts Sentences

\begin{abstract}
Abstrak
Penelitian dilatarbelakangi hasil keterampilan menulis karangan narasi peserta didik belum mencapai kriteria ketuntasan minimal (KKM). Penelitian bertujuan untuk meningkatkan keterampilan menulis karangan narasi dengan penerapan model pembelajaran cooperative learning type concept sentences pada peserta didik kelas IV SDN Soropadan tahun ajaran 2020/2021. Penelitian ini merupakan penelitian tindakan kelas dengan langkah perencanaan, pelaksanaan, pengamatan, dan refleksi yang dilaksanakan dalam tiga siklus. Hasil penelitian menunjukkan adanya peningkatan ketuntasan klasikal dari $39 \%$ dengan nilai rata-rata 75,42 menjadi $67 \%$ dan nilai rata-rata 80,97 pada siklus I, $89 \%$ dan nilai rata-rata 84,58 pada siklus II dan $94 \%$ dengan rata-rata 87,92 pada siklus III. Kesimpulan penelitian yaitu penerapan model pembelajaran cooperative learning type concept sentences dapat meningkatkan keterampilan menulis karangan narasi pada peserta didik kelas IV SDN Soropadan Surakarta tahun ajaran 2020/2021.
\end{abstract}

Kata kunci: Keterampilan Menulis, Karangan Narasi, Concepts Sentences 


\section{PENDAHULUAN}

Pendidikan merupakan suatu proses transfer ilmu berupa pengajaran dan bimbingan yang dilaksanakan secara terus menerus dan terencana dari generasi tua kepada generasi muda berupa sikap, pengetahuan dan keterampilan yang diperlukan individu agar sejalan dengan diri, masyarakat serta bangsanya. John Dewey (1916) menyebutkan bahwa pendidikan adalah sebagai proses yang berupa pengajaran dan bimbingan, bukan paksaan, yang terjadi karena adanya interaksi dengan masyarakat (Munib 2011: 33). Tujuan dari pendidikan ini tercantum dalam Undang-undang nomer 20 tahun 2003 tentang Sistem Pendidikan Nasional pasal 3. Dalam mencapai tujuan tersebut guru sebagai pendidik memiliki peran yang tidak dapat dinafikan.

Pendidik diharapkan mampu menumbuhkan keterampilan peserta didik dalam mengikuti perkembangan pembelajaran abad-21. Pembelajaran saat ini menuntut peserta didik untuk memiliki empat keterampilan dasar yang disebut 4C, yakni (1) kreativitas dan inovasi (creativity and innovation), (2) berpikir kritis dan pemecahan masalah (critical thinking and problem solving), (3) komunikasi (communication), dan (4) kolaborasi (collaboration). Keterampilan ini diajarkan dalam berbagai mata pelajaran serta diterapkan di berbagai aspek keterampilan lainnya. Salah satu mata pelajaran yang menuntut keterampilan tersebut yaitu Bahasa Indonesia.

Bahasa Indonesia merupakan salah satu pelajaran wajib diajarkan di sekolahsekolah di Indonesia dari tingkat PAUD sampai doktor. Bahasa Indonesia memiliki empat keterampilan dasar yang saling terkait dan harus dikuasai oleh setiap peserta didik. Empat keterampilan tersebut yaitu mendengarkan, berbicara, membaca, dan menulis. Keempat keterampilan tersebut bisa berperan saling melengkapi, bisa pula saling menggantikan. Penyampaian materi dengan bahasa yang baik dan benar akan lebih mudah dipahami oleh peserta didik. Penyampaian materi bisa dalam bentuk lisan maupun tulisan. Bentuk lisan disampaikan dengan cara pendidik berbicara, sedangkan peserta didik mendengarkan. Bentuk tulisan yaitu seorang pendidik memberikan materi secara tertulis dan peserta didik memahami dengan membaca. Penyampaian secara lisan mendukung penyampaian materi secara tertulis, begitu juga sebaliknya. Maka dari itu, kemampuan menulis menjadi modal penting bagi siapapun yang ingin menyampaikan pemahamannya.

Keterampilan menulis berarti keterampilan seseorang untuk menyampaikan ide, pendapat, gagasan, perasaan dan pengalaman dalam bentuk tulisan dengan menggunakan bahasa yang baik dan benar. Dalam tulisan yang baik harus ada keterjalinan antara unsur bahasa dan unsur isi sehingga terbentuk tulisan yang runtut dan terpadu. Penilaian keterampilan menulis peserta didik terdiri dari gagasan yang disampaikan, struktur isi, tata kalimat atau bahasa, diksi, dan PUEBI. Penilaian menjadi lebih penting ketika tujuan dari sebuah tulisan digunakan untuk menarasikan suatu hal. Narasi bertujuan untuk memberitahukan suatu peristiwan dan/atau informasi secara runtut dan terperinci.

Berkaitan dengan hal tersebut, ditemukan data bahwa ada beberapa permasalahan yang menghambat keterampilan menulis pada peserta didik antara lain yaitu kurang sistematisnya pelaksanaan pembelajaran menulis di sekolah dasar, kurangnya latihan dan pembiasaan pendidik kepada peserta didik dalam hal menulis, serta rendahnya literasi peserta didik terhadap pengetahuan-pengetahuan yang seharusnya dimiliki dalam pembelajaran abad 21. Permasalahan - permasalahan tersebut ditemukan di SDN Sorpadan Surakarta yang disebabkan oleh (1) Rasio pendidik dan peserta didik ideal, namun mencapai batas maksimal sehingga proses pembelajaran kurang optimal; (2) Rendahnya pemahaman peserta didik mengenai perbedaan teks fiksi dan teks nonfiksi; (3) Rendahnya keterampilan peserta didik dalam menuliskan ide-ide untuk menyusun karangan narasi. Hal ini ditunjukkan dengan tingkat ketuntasan peserta didik yang hanya berjumlah 7 dari 18 atau sekitar $39 \%$, sedangkan $61 \%$ lainnya masih belum mampu mencapai KKM. 
Pembelajaran dikatakan berhasil jika $75 \%$ peserta didik dalam kelas mampu memperoleh nilai di atas KKM. Peran guru dalam hal ini menjadi penting, sebagai pendidik sekaligus fasilitator, guru diharuskan untuk melakukan upaya perbaikan dalam meningkatkan kemampuan peserta didik. Guru harus mampu memberikan inovasi pembelajaran yang berbeda untuk meningkatkan kualitas pembelajaran. Salah satu upaya guru dalam memingkatkan kualitas pembelajaran yaitu dengan menerapkan model pembelajaran yang inovatif, menarik, dan efektif. Solusi model pembelajaran yang tepat untuk meningkatkan keterampilan menulis peserta didik yaitu Cooperative Learning Type Concept Sentences. Huda (2013) menyatakan, Concept Sentence merupakan model pembelajaran yang dilakukan dengan memberikan kartukartu yang berisi beberapa kata kunci kepada peserta didik, kemudian kata kunci-kata kunci tersebut disusun menjadi beberapa kalimat dan dikembangkan menjadi paragrafparagraf. Model ini dilaksanakan dengan mengelompokkan peserta didik secara acak dan variasi dengan harapan bahwa peserta didik mampu membuat kalimat dengan minimal empat kata kunci sesuai materi yang disajikan.

Berdasarkan uraian permasalahan tersebut, maka terbentuk suatu rumusan apakah penerapan model cooperative learning type concept sentences dapat meningkatkan keterampilan menulis karangan narasi peserta didik kelas IV sekolah dasar. Rumusan ini mendasari tujuan dilakukannya tindakan yaitu untuk meningkatkan keterampilan menulis karangan narasi peserta didik kelas IV SDN Soropadan Surakarta tahun ajaran 2020/2021.

\section{METODE}

Metode yang digunakan yaitu Penelitian Tindakan Kelas (PTK) yang dilaksanakan dalam tiga siklus secara daring (dalam jaringan). Masing-masing siklus terdiri dari empat tahap yaitu (1) tahap perencanaan, (2) tahap pelaksanaan, (3) tahap pengamatan, dan (4) tahap refleksi. Pelaksanaan penelitian yaitu di SDN Soropadan Surakarta dengan subjek peserta didik kelas IV yang berjumlah 18 anak, terdiri dari 7 peserta didik laki-laki dan 11 peserta didik perempuan. Jumlah ini diambil secara acak dari total keseluruhan 32 peserta didik.

Data hasil penelitian berupa data kuantitatif yang bersumber pada hasil perolehan nilai keterampilan menulis peserta didik. Penilaian ini terdiri dari aspek struktur kalimat, penggunaan bahasa baku, penggunaan PUEBI yang tepat, keutuhan cerita serta sistematis dan urutan cerita. Data diolah dengan menggunakan teknik triangulasi sumber dan kemudian dianalisis. Analisis data terdiri dari reduksi data, penyajian data, dan kesimpulan (Sugiyono, 2015: 336).

Indikator keberhasilan penelitian yaitu ketuntasan minimal peserta didik pada keterampilan menulis karangan narasi menggunakan model cooperative learning type concept sentences mencapai $75 \%$ dengan nilai KKM sebesar 75 .

\section{HASIL DAN PEMBAHASAN}

Penerapan model cooperative learning type concept sentences dalam meningkatkan keterampilan menulis karangan narasi peserta didik dilaksanakan dalam tiga siklus. Setiap siklus terdiri dari 1 pertemuan yang dilaksanakan dalam 1 pembelajaran tematik, yang didalamnya termuat mata pelajaran Bahasa Indonesia. Pelaksaaan setiap pembelajaran menerapkan pendekatan saintifik untuk meningkatkan keaktifan peserta didik dalam mengikuti kegiatan pembelajaran.

Pembelajaran dilaksanakan dengan mengikuti langkah-langkah penerapan model cooperative learning type concept sentences yaitu (1) penyampaian materi, (2) pembentukan kelompok heterogen, (3) pemilihan kata kunci, dan (4) penugasan. Pada langkah pembentukan kelompok heterogen terjadi sedikit modifikasi karena pembelajaran daring,, yaitu peserta didik yang seharusnya berkelompok dengan peserta didik lain akan berkelompok dengan keluarga/pendamping di rumah. 
Hasil rekapitulasi data penelitian tindakan kelas ini menunjukkan adanya peningkatan hasil keterampilan menulis karangan narasi peserta didik kelas IV SD Negeri Soropadan Surakarta pada prasiklus, siklus I, siklus II, dan siklus III mengalami peningkatan. Peningkatan tersebut dapat dilihat pada tabel dan diagram berikut.

Tabel 1. Perbandingan Data Keterampilan Menulis Karangan Narasi Prasiklus, Siklus, Siklus II, dan Siklus III

\begin{tabular}{lcccc}
\hline \multicolumn{1}{c}{ Pencapaian } & Prasiklus & $\begin{array}{c}\text { Siklus } \\
\text { I }\end{array}$ & Siklus II & Siklus II \\
\hline Nilai Tertinggi & 87,5 & 95 & 100 & 100 \\
Nilai Terendah & 65 & 70 & 70 & 70 \\
Rata-rata & 75,42 & 80,97 & 84,58 & 87,92 \\
Ketuntasan & $39 \%$ & $67 \%$ & $89 \%$ & $94 \%$ \\
\hline
\end{tabular}

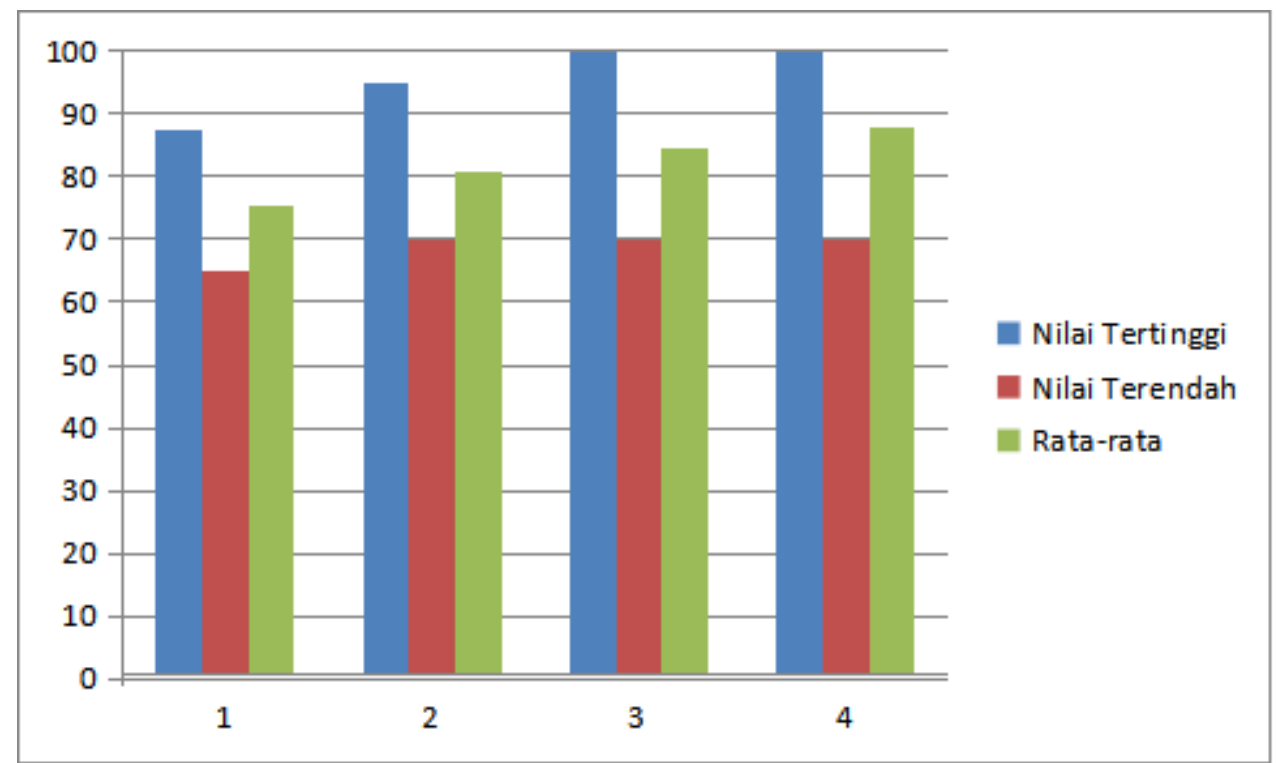

Gambar 1. Diagram Perbandingan Hasil Menulis Karangan Narasi PraSiklus, Siklus I, Siklus II dan Siklus III

Berdasarkan tabel 1 dapat dijabarkan bahwa pada adanya siklus (kegiatan prasiklus) nilai tertinggi yang diperoleh peserta didik yaitu sebesar 87,5. Tingkat ketuntasan peserta didik hanya sebesar $39 \%$ dengan rata-rata nilai kelas 75,42 . Data ini menunjukkan keterampilan menulis karangan narasi peserta didik tergolong rendah dan tingkat ketuntasan juga masih cukup jauh dari standar minimal pembelajaran.

Pada siklus I terjadi peningkatan keterampilan menulis karangan narasi pada peserta didik yang ditunjukkan dengan data. Berdasarkan data, diperoleh $67 \%$ peserta didik sudah mengalami ketuntasan belajar. Nilai rata-rata kelas yang diperoleh adalah 80,97 . Secara individu nilai terendah peserta didik yaitu 70 sedangkan nilai tertinggi mencapai 95. Dari 18 peserta didik, 12 peserta didik atau 67\% mengalami ketuntasan, sedangkan 6 peserta didik atau 33\% dinyatakan tidak tuntas karena mendapat nilai di bawah 75 atau KKM.

Penelitian dilanjutkan pada siklus II yang kembali memberikan hasil cukup memuaskan. Berdasarkan hasil belajar aspek keterampilan peserta didik dalam menulis karangan narasi pada siklus II dapat diketahui bahwa sebesar 89\% peserta 
didik sudah mengalami ketuntasan belajar dalam menulis karangan narasi. Nilai ratarata kelas yang diperoleh adalah 84,58. Secara individu nilai terendah yaitu 70 diperoleh oleh 2 peserta didik sedangkan nilai tertinggi 100 yang diperoleh oleh 1 peserta didik. Dari 18 peserta didik, 16 diantaranya sudah mampu mencapai nilai KKM yang ditentukan peneliti yaitu 75, sedangkan 2 sisanya masih memerlukan bimbingan agar mampu mengembangkan daya kreativitasnya lagi.

Pada siklus III, terjadi peningkatan kembali berdasarkan data perolehan nilai peserta didik dalam keterampilan menulis karangan narasi, diperoleh nilai rata-rata 87,92. Peroleh nilai tertinggi yaitu 100 yang diraih oleh 2 peserta didik dan nilai terendah 70 diraih oleh 1 peserta didik. Persentase ketuntasan pada siklus III mencapai 94\% dengan 17 peserta didik memperoleh nilai diatas KKM. Berdasarkan pada hasil penelitian pada siklus III, ketuntasan minimal telah melampaui $75 \%$, sehingga penelitian diakhiri pada siklus III.

Data yang terdapat pada tabel maupun gambar membuktikan bahwa penelitian terdahulu oleh Hapsari, dkk (2018) yang menyatakan bahwa penerapan concept sentences mampu meningkatkan keterampilan menulis peserta didik sampai pada skor rata-rata 86,4. Selain penelitian Hapsari, ada juga penelitian yang dilakukan oleh Apriliana dan Hermawati (2020) yang menunjukkan bahwa terjadi peningkatan keterampilan menulis peserta didik dari $26 \%$ pada kondisi awal menjadi $65 \%$ pada siklus 1 dan meningkat kembali menjadi $83 \%$ pada akhir siklus II.

Secara umum, perolehan hasil penelitian ini bukan tanpa kendala. Beberapa kendala teknis yang dihadapi yaitu (1) pelaksanaan pembelajaran secara daring yang menyebabkan pembelajaran kurang optimal, (2) keterbatasan sarana sehingga tidak semua peserta didik mampu mengikuti pembelajaran daring, (3) waktu pengerjaan tugas yang terkadang kurang tepat waktu. Kendala-kendala ini dapat diatasi dengan cukup mudah yaitu penjelasan melalui pesan suara WA. Sedangkan kendala lain yaitu kehadiran peserta didik. Tidak semua peserta didik dapat mengikuti kegiatan pembelajaran secara langsung, sehingga pada akhirnya peneliti memutuskan untuk menggunakan sampel dari subjek utama.

Berdasarkan uraian hasil penelitian, dapat disimpulkan bahwa penerapan model cooperative learning type concept sentences dapat meningkatkan keterampilan menulis peserta didik kelas IV SDN Soropadan Surakarta.

\section{SIMPULAN}

Berdasarkan uraian hasil da pembahasan Penelitian Tindakan Kelas (PTK), maka dapat disimpulkan bahwa (1) model concept sentence dapat meningkatkan keterampilan menulis karangan narasi pada peserta didik kelas IV SD Negeri Soropadan, Surakarta tahun ajaran 2020/2021; (2) keterampilan menulis karangan narasi menggunakan model concept sentence mengalami peningkatkan dari nilai ratarata kelas dari 75,42 pada prasiklus menjadi 80,97 pada siklus I, kemudian menjadi 84,58 pada siklus II dan berakhir dengan 87,92 pada akhir siklus III; (3) persentase ketuntasan minimal peserta didik pada keterampilan menulis karangan narasi dengan menggunakan model concept sentences mengalami peningkatan secara signifikan, dari $39 \%$ pada prasiklus menjadi $76 \%$ pada siklus I, lalu menjadi $89 \%$ pada siklus II dan berakhir menjadi $94 \%$ pada akhir siklus III.

Berkaitan dengan hasil penelitian, ada beberapa saran yang bisa diterapkan oleh pendidik untuk meningkatkan kualitas pembelajaran. Saran tersebut antara lain (1) melakukan persiapan dan perencanaan matang sebelum melaksanakan pembelajaran dengan melihat potensi, kelebihan dan kelemahan peserta didik; (2) memilih media yang sesuai dengan materi sehingga meningkatkan antusiasme peserta didik dalam mengikuti pembelajaran; (3) melakukan pembimbingan individu terhadap peserta didik yang belum mencapai tingkat kognitif yang diharapkan; (4) mengadakan evaluasi 
proses dan hasil dalam pembelajaran untuk mengukur tingkat kemampuan peserta didik.

\section{DAFTAR PUSTAKA}

Apriliana, Anggi Citra dan Wina Hermawati. (2020). Penggunaan Model Pembelajaran Concept Sentence Untuk Meningkatkan Aktivitas Siswa dan Keterampilan Menulis Karangan Narasi. Jurnal Ilmiah Pendidikan Dasar Universitas Sebelas April Sumedang. Diakses pada 22 November 2020 dari https://journal.unpas.ac.id/index.php/pendas/article/view/2862.

Aqib, Zainal \& M. Chotibuddin. (2018). Teori dan Aplikasi Penelitian Tindakan Kelas (PTK). Yogyakarta: CV. Budi Utama.

Ardiawan, I Ketut Ngurah \& I Gede Arya Wiradnyana. (2020). Kupas Tuntas Penelitian Tindakan Kelas (Teori, Praktik dan Publikasinya). Badung, Bali: Nilacakra.

Frydenberg, M. E., Andone, D. (2011). Learning for 21st Century Skills. IEEE's International Conference on Information Society, London, 27-29 June 2011, 314318. Diakses pada 22 November 2020.

Hapsari, Dina Kartika, dkk. (2018). Model Concept Sentence dalam Meningkatkan Keterampilan Menulis Narasi. Jurnal Universitas Negeri Malang volume 26 no. 1. Diakses pada 23 November 2020 dari http://journal2.um.ac.id/index.php/wsd/.

Huda, Miftahul. (2013). Model-Model Pengajaran dan Pembelajaran. Yogyakarta: Pustaka Pelajar.

Kurniawan, Nurhafit. (2017). Penelitian Tindakan Kelas. Yogyakarta: Penerbit Deepublish (CV Budi Utama).

Sadono, Fitria Sri. (2018). Penerapan Model Concept Sentence dengan Media Kartu Kata untuk Meningkatkan Keterampilan Menulis Narasi Siswa Kelas IV-A SDN Tawangmas 01 Semarang. Diakses pada 15 Desember 2020 dari https://lib.unnes.ac.id/21668/1/1401411252-s.pdf

Shoimin, Aris. (2014). 68 Model Pembelajaran Inovatif dalam Kurikulum 2013. Yogyakarta: AR-Ruzz Media

Sugiono. (2016). Metode Penelitian Pendidikan (Pendekatan Kuantitatif, Kualitatif, da $R \& D)$. Bandung: Alfabeta. 